\title{
Prediction of the number of consumed disc cutters of tunnel boring machine using intelligent methods
}

\author{
Alireza Afradi ${ }^{1 \otimes(\mathbb{D}}$, Arash Ebrahimabadi ${ }^{2 *} \otimes\left(\mathbb{D}\right.$, Tahereh Hallajian $^{1 \otimes(\mathbb{0})}$ \\ ${ }^{1}$ Department of Mining and Geology, Qaemshahr Branch, Islamic Azad University, Qaemshahr, 4765161964, Iran \\ ${ }^{2}$ Department of Petroleum, Mining and Material Engineering, Central Tehran Branch, Islamic Azad University, Tehran, 13117773591, Iran \\ *Corresponding author: e-mail A.Ebrahimabadi@iauctb.ac.ir, tel. +982144600200
}

\begin{abstract}
Purpose. Disc cutters are the main cutting tools for the Tunnel Boring Machines (TBMs). Prediction of the number of consumed disc cutters of TBMs is one of the most significant factors in the tunneling projects. Choosing the right model for predicting the number of consumed disc cutters in mechanized tunneling projects has been the most important mechanized tunneling topics in recent years.
\end{abstract}

Methods. In this research, the prediction of the number of consumed disc cutters considering machine and ground conditions such as Power (KW), Revolutions per minute (RPM) (Cycle/Min), Thrust per Cutter (KN), Geological Strength Index (GSI) in the Sabzkooh water conveyance tunnel has been conducted by multiple linear regression analysis and multiple nonlinear regression, Gene Expression Programming (GEP) method and Support Vector Machine (SVM) approaches.

Findings. Results showed that the number of consumed disc cutters for linear regression method is $R^{2}=0.95$ and $\mathrm{RMSE}=0.83$, nonlinear regression method is $-R^{2}=0.95$ and $\mathrm{RMSE}=0.84$, Gene Expression Programming (GEP) method is $-R^{2}=0.94$ and RMSE $=0.95$, Support Vector Machine $(\mathrm{SVM})$ method is $-R^{2}=0.98$ and $\mathrm{RMSE}=0.45$.

Originality. During the analyses, in order to evaluate the accuracy and efficiency of predictive models, the coefficient of determination $\left(\mathrm{R}^{2}\right)$ and root mean square error (RMSE) have been used.

Practical implications. Results demonstrated that all four methods are effective and have high accuracy but the method of support vector machine has a special superiority over other methods.

Keywords: regression, gene expression programming, support vector machine, Sabzkooh water conveyance tunnel

\section{Introduction}

Over the past few decades, the technology of rock TBMs developed greatly. These machines have now reached a stage that they can excavate nearly any kind of rock or ground, but excavating with machine is highly risky, because it's always possible to encounter a ground that the machine cannot excavate or the ground is such hard and abrasive that cutting tool consumption rate reach higher leading to impose more costs to the project. Predicting the number of consumed disc cutters is an important factor in improving the performance of TBMs. It should be noted that the lower the number of discs consumed, the TBM costs will also be reduced. Disc cutters are the most important cutting tool used in TBM. At present, single disc cutters are the most common and effective cutting tool for rock excavation.

The design of the discs for optimal operation requires understanding of the interaction between disc, rock and the forces on the disc when cutting the rock. Researchers have been studied the forces involved in the disc and their depend- ence on rock properties, diameter, disc geometry and depth of penetration in the rock for many years. Disc consumption rate of TBM in soft and hard rocks that are in contact with excavated materials is one of the effective factors in the mechanized tunneling process. One of the most critical excavating conditions using the TBM is the impact with abrasive soils and rocks, followed by excessive wear of the disc cutters, which has been recorded and reported in many tunneling projects around the world. Therefore, a general assessment of the consumption of TBM disc cutters before excavating and its refinement during tunnel excavating operations is necessary due to its direct impact on excavating efficiency.

Accurate estimation of the number of disc cutters required for excavating a certain area of the tunnel is a very difficult and complex task due to numerous and effective parameters such as lithological and geological conditions, TBM specifications and various performance parameters. Akiyama [1] presented a theory of the rock-breaking function of the disc cutter. Evans [2] estimated relative efficiency of picks and discs for 
cutting rock. Snowdon et al. [3] studied the cutting mechanism on discs in selected rocks. Sanio [4] proposed a model to predict the performance of disc cutters in anisotropic rocks. Rostami [5] developed a force estimation model for rock fragmentation with disc cutters. Frenzel et al. [6] studied at factors influencing disc cutter wear. Roby et al. [7] proposed a new model for disc cutter design. Numerous researchers [8]-[14] have attempted to develop predictive models for disc cutters. In the present study, the number of consumed disc cutters in the Sabzkooh water conveyance tunnel will be predicted using linear and nonlinear regression methods, support vector machine and gene expression programming algorithm.

\section{Methods and materials}

\subsection{Describing the case study}

Sabzkooh water conveyance tunnel is located in the southsouth east of Chaharmahal and Bakhtiari province, southwest of Borujen city, and east-south east of Ardal and Nagan cities in Iran. The northern portal of the tunnel is located in the southern part of the Chaghakhor Dam Lake and the north of the Klar Mountains. Access to it is through the BoroujenBoldaji cities to the village of Saki Abad and the Petrochemical town, as well as the Shahrekord-Nagan road to the villages of Galugerd and Saki Abad. The southern crater of the tunnel is located in the central part of Sabzkooh and southern Klar Mountains. This section is accessible through the route of Shahrekord-Nagan to the villages of Joghdan-Chahartagh and Chehraz. At present, this route is paved to the Hyderabad village and the rest of the route is towards the southern crater of the tunnel [15]. Position and region of Sabzkooh water conveyance tunnel, As can be seen in Figure 1.

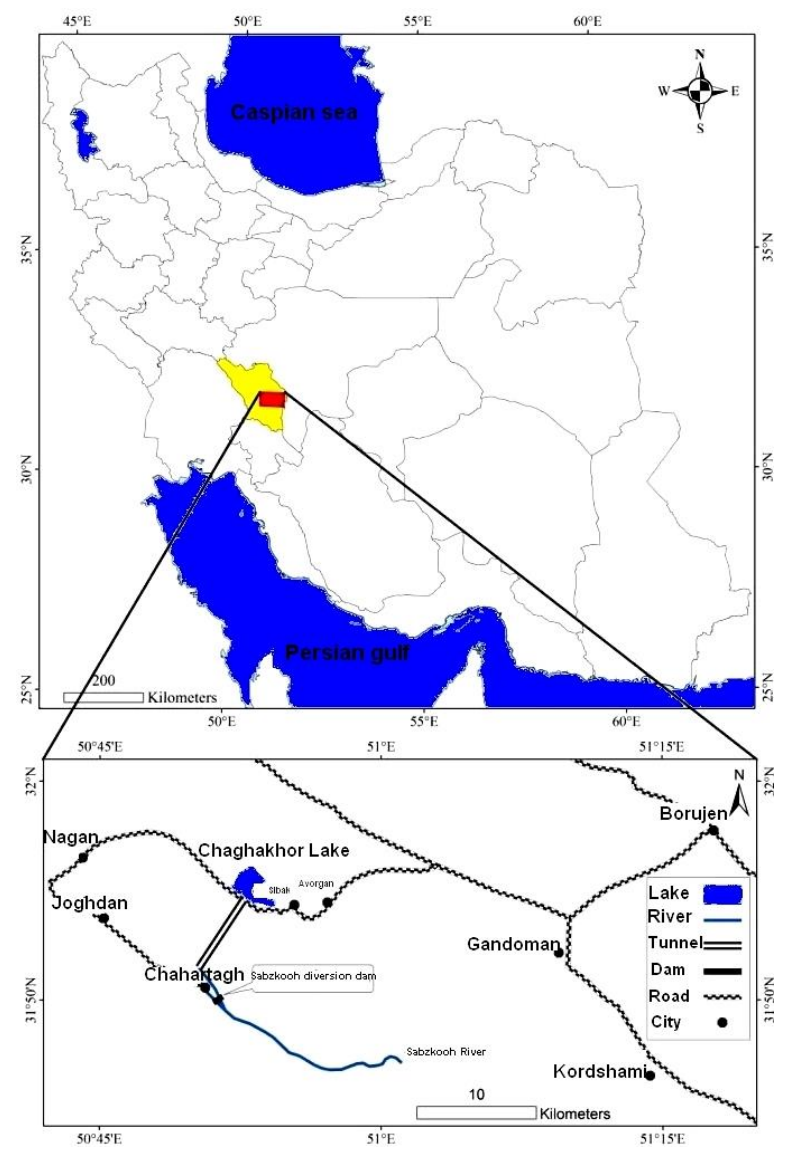

Figure 1. Position and region of Sabzkooh water conveyance tunnel

\subsection{Linear regression}

It is one of the methods of regression analysis. In linear regression, the dependent variable is a linear combination of input or independent variables [16]. Of course, the dependent variable does not need to be linear in relation to the independent variables. The purpose of the regression analysis is to identify the linear model of this relationship. In the following, we use the dependent variable instead of the variable of the response and the independent variable instead of the descriptive variable. Since independent variables may be involved and unknown factors also play a role in determining the value of the dependent variable, the regression model with the most suitable number considered an independent variable and considered the error rate as representative of other random factors that could not be identified, which is expected to be less dependent on the dependent variable variations [17], [18].

\subsection{Nonlinear regression}

Nonlinear regression can examine and measure model relationships among independent and independent variables..In nonlinear regression, at least one derivative of the function relative to the parameters depends on at least one of the parameters. This kind of regression (nonlinear regression) is a method for finding a nonlinear model to find the relation between a dependent variable and a set of independent variables [19], [20]. Unlike the old way of linear regression that limits the calculation of linear model; nonlinear regression can examine and measure the model relationships arbitrarily and voluntarily between independent and independent variables [21], [22]. The use of this is based on the estimation algorithm. It is worth noting that this method is not done for multi-formula (complex) models, which can be calculated by the old way of linear regression [23].

\subsection{Gene Expression Programming (GEP)}

The GEP algorithm actually gathers the prevailing view of two pre-inherit algorithms to cover the weaknesses of the two. In this method, the chromosome genotype is similar to the genetic algorithm of a linear structure, and the phenotype of the chromosomes is a tree structure of variable length and size similar to genetic programming algorithm. Hence, the GEP algorithm, by overcoming the dual role of chromosomes in its predecessor algorithms, allows the application of multiple genetic operators with a permanent health guarantee for child's chromosomes, and at a rate faster than GP due to structural variation above GA, the space of possible responses to find a fuller picture. In fact, GEP has succeeded in passing through the first and second thresholds in natural evolution processes (Replicator Threshold and Phenotype Threshold) from this perspective. Gene Expression Programming (GEP) method is based on the Darwin's Theory of Evolution. This method is the combining and developing two methods of genetic algorithm and genetic programming, which was invented by Ferreira [24]. In this method, linear and simple chromosomes with constant length, similar to the genetic algorithm and branch structures with varying sizes and shapes, which include the set of terminals (problem variables), and the set of functions (the principal mathematical operators), are combined similar to decomposition trees in genetic programming [25], [26]. The first phase in GEP is the formation of a primary population of solutions [27]. Then the chromosomes are represented by expression tree. In the next step, the degree of compatibility of each member of the 
chromosome population is determined by the fit function and finally provides a suitable solution [28]. The values of the parameters used by GEP to predict the number of consumed disc cutters in the Sabzkooh water conveyance tunnel are presented in Table 1.

Table 1. GEP parameters

\begin{tabular}{lc}
\hline \multicolumn{1}{c}{ Parameter description } & Parameter value \\
\hline Head Size & 10 \\
\hline Chromosomes & 30 \\
\hline Number of genes & 4 \\
\hline Mutation Rate & 0.00138 \\
\hline Inversion Rat ( & 0.1 \\
\hline One Point Recombination Rate & 0.00277 \\
\hline Two Point Recombination Rat ( & 0.00277 \\
\hline Gene Recombination Rate & 0.00277 \\
\hline IS Transposition Rate & 0.00546 \\
\hline RIS Transposition Rat & 0.00546 \\
\hline Gene Transposition Rat ( & 0.00546 \\
\hline Fitness Function & RMSE \\
\hline Linking Function & $(+)$ \\
\hline
\end{tabular}

\subsection{Support vector machine}

SVM is a type of learning system that is used to classify the input data and to estimate the fitting function of the data, so that the least error occurs in sorting the data and fitting function. Data are divided into three categories: training data, validation and testing so that training data will train support vector machine, verify accuracy of the machine parameters, and finally use this machine for classification or estimation of test data. this method is based on constrained optimization theory which uses the principle of minimizing the structural error and leads to a general optimal response. Support Vector Machine can also be used as a regression technique.
The basis of SVM classifier is a data linear classification, and in linear division of data, we try to select a line that has a more reliable margin[29], [30]. Before linear division for the machine can classify data with high complexity, we take data by phi function into a much larger space [31], [32]. To solve a very high -dimension problem using these methods, we use the Lagrange duality theorem for converting the desired minimization problem to its dual form, which, instead of the complex phi function, which takes us to a high-dimension space, a simpler function with the name of the kernel function appears that is phi function vector product [33], [34]. Various kernel functions, such as Linear, Gaussian, RBF, Polynomial, and Sigmoidal cores can be used [35]. The settings used in SVM to predict the number of consumed disc cutters in the Sabzkooh water conveyance tunnel are as described in Table 2.

\section{Table 2. SVM parameters}

\begin{tabular}{cccccc}
\hline Model & Kernel & Degree & $\varepsilon$ & $C$ & $\sigma$ \\
\hline$\varepsilon-S V R$ & $\begin{array}{c}\text { Radial Basis } \\
\text { Function (RBF) }\end{array}$ & 2 & 0.1 & 1000 & 0.5 \\
\hline
\end{tabular}

\subsection{Database}

Input and output variables of the predictive models of the number of consumed disc cutters in the Sabzkooh water conveyance tunnel are shown in Table 3 and the descriptive statistics of data shown in Table 4.

Table 3. Input and output variables of the predictive models

\begin{tabular}{cc}
\hline Input & $\begin{array}{c}\text { Power (KW), Revolutions per minute } \\
\text { (RPM)(Cycle/Min), Thrust per Cutter (KN), } \\
\text { Geological Strength Index (GSI) }\end{array}$ \\
\hline Output & Number of consumed disc cutter \\
\hline
\end{tabular}

\section{Table 4. Descriptive statistic of database}

\begin{tabular}{lccccc}
\hline Model & $\begin{array}{c}\text { Power } \\
(\mathrm{KW})\end{array}$ & $\begin{array}{c}\text { Revolutions } \\
\text { per minute } \\
(\mathrm{RPM})(\text { cycle/min) }\end{array}$ & $\begin{array}{c}\text { Thrust per } \\
\text { cutter (KN) }\end{array}$ & $\begin{array}{c}\text { Geological } \\
\text { Strength } \\
\text { Index (GSI) }\end{array}$ & $\begin{array}{c}\text { Number of } \\
\text { consumed } \\
\text { disc cutter }\end{array}$ \\
\hline Mean & 557 & 6.1379 & 252.8117 & 49.8093 & 15.40 \\
\hline $\mathrm{N}$ & 99 & 99 & 99 & 99 & 99 \\
\hline Std. Deviation & 126.960 & 1.75778 & 30.04549 & 13.47463 & 3.964 \\
\hline Minimum & 440 & 2.97 & 160.96 & 27 & 9 \\
\hline Maximum & 1100 & 10.00 & 310.86 & 83 & 22 \\
\hline Variance & 16119.050 & 3.090 & 902.731 & 181.566 & 15.713 \\
\hline Harmonic Mean & 534 & 5.6483 & 248.8623 & 46.0056 & 14.36 \\
\hline Geometric Mean & 545 & 5.8902 & 250.9114 & 47.9256 & 14.88 \\
\hline Std. Error of Mean & 12.760 & 0.17666 & 3.01969 & 1.35425 & 0.398 \\
\hline
\end{tabular}

\subsection{Evaluation criteria}

The definition of determination coefficient $\left(R^{2}\right)$ is relatively simple: "determination coefficient $\left(R^{2}\right)$ indicates that the percentage of variations of a variable is dependent on the instrument of the independent variable" or, in other words, the determination coefficient indicates that "how much of the variation of the dependent variable is affected by the independent variable and the rest of the dependent variable changes are related to other factors". The root mean squared error (RMSE) is considered as a measure of absolute error between precipitation and observation. In this study, in order to evaluate the accuracy and performance of the models, the coefficients of determination $\left(R^{2}\right)$ and root mean square error (RMSE) is used [36].

\section{The results of modelling}

\subsection{Predicting by linear regression}

Linear regression analysis is applied to the database to obtain a prediction model for the number of consumed disc cutter. With this respect, the determination coefficient of the multivariate linear regression model is presented in Table 5. The regression coefficients related to the predictive model of consumed disc cutter in this tunnel are presented in Table 6, as well as the linear relationship achieved from these coefficients between the independent variables and number of consumed disc cutter used, as described by Equation 1. Also, the distribution diagram and the matching diagram between the measured values of number of consumed disc cutter or target and the predicted number of consumed disc cutter are shown in Figures 2 and 3, respectively. 
Table 5. Coefficient of determination of linear regression

\begin{tabular}{ccccc}
\hline Model & R & R Square & $\begin{array}{c}\text { Adjusted } \\
\text { R Square }\end{array}$ & $\begin{array}{c}\text { Std. Error } \\
\text { of the } \\
\text { Estimate }\end{array}$ \\
\hline 1 & $0.978 \mathrm{a}$ & 0.956 & 0.955 & 0.8447 \\
\hline
\end{tabular}

*a. Predictors: (constant), Power (KW), RPM (cycle/min), Thrust per Cutter (KN), GSI

Table 6. Regression coefficients of linear regression

\begin{tabular}{lccccc}
\hline \multirow{2}{*}{ Model } & \multicolumn{2}{c}{$\begin{array}{c}\text { Unstandardized } \\
\text { coefficients }\end{array}$} & $\begin{array}{c}\text { Standardized } \\
\text { coefficients }\end{array}$ & \multirow{2}{*}{$\mathrm{t}$} & Sig. \\
\cline { 2 - 5 } & $\mathrm{B}$ & Std. Error & Beta & & \\
\hline Constant & 0.381 & 0.348 & & 1.097 & 0.275 \\
\hline Power (KW) & 0.011 & 0.001 & 0.389 & 8.899 & 0.000 \\
\hline $\begin{array}{l}\text { RPM } \\
\text { (cycle/min) }\end{array}$ & 0.268 & 0.086 & 0.124 & 3.128 & 0.002 \\
\hline $\begin{array}{l}\text { Thrust per } \\
\text { Cutter (KN) }\end{array}$ & 0.019 & 0.003 & 0.234 & 5.464 & 0.000 \\
\hline GSI & 0.089 & 0.016 & 0.302 & 5.476 & 0.000 \\
\hline
\end{tabular}

${ }^{*}$ a. Dependent Variable: Number of consumed disc cutter

Number of consumed disc cutter $=0.381+0.011 P O W E R+$

$+0.268 R P M+0.019$ Thrust per Cutter +0.089 GSI .

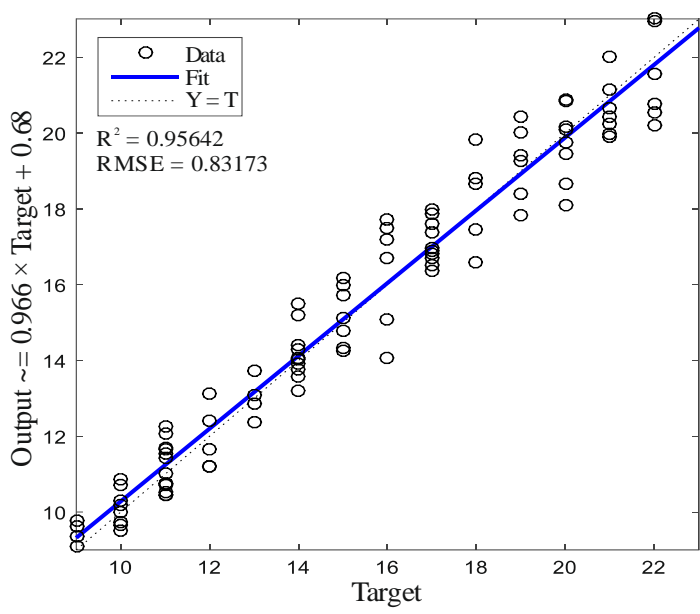

Figure 2. Distribution diagram by linear regression

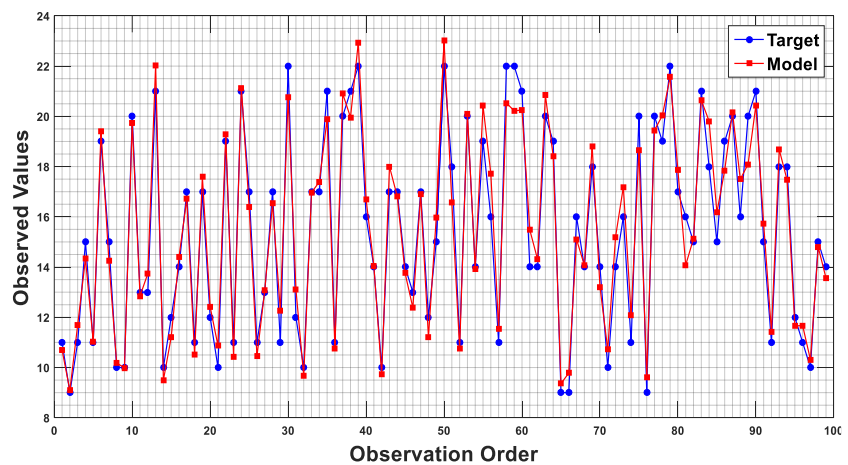

Figure 3. Diagram of matching by linear regression

\subsection{Predicting by Nonlinear Regression}

As part of study, the database was analyzed through nonlinear regression modeling. The determination coefficient of the multivariate nonlinear regression model to predict the number of TBMs consumed disc cutter is shown in Table 7. The regression coefficients related to the predictive model of the number of consumed disc cutter in this tunnel is listed in
Table 8 , as well as the nonlinear relationship created by these coefficients between the independent variables and the number of consumed disc cutter, are described in Equation 2. Moreover, the distribution diagram and the matching diagram of the measured values and the predicted values of the number of consumed disc cutter by predictive model are shown in Figures 4 and 5, respectively.

Table 7. Coefficient of determination of nonlinear regression

\begin{tabular}{ccccc}
\hline Model & R & R Square & $\begin{array}{c}\text { Adjusted } \\
\text { R Square }\end{array}$ & $\begin{array}{c}\text { Std. Error } \\
\text { of the } \\
\text { Estimate }\end{array}$ \\
\hline 1 & $0.977 \mathrm{a}$ & 0.955 & 0.953 & 0.8599 \\
\hline
\end{tabular}

*a. Predictors: (constant), Power (KW), RPM (cycle/min), Thrust per Cutter (KN), GSI

Table 8. Regression coefficients of nonlinear regression

\begin{tabular}{lcccccc}
\hline \multirow{2}{*}{ Model } & \multicolumn{2}{c}{$\begin{array}{c}\text { Unstandardized } \\
\text { coefficients }\end{array}$} & $\begin{array}{c}\text { Standardized } \\
\text { coefficients }\end{array}$ & \multirow{2}{*}{ t } & Sig. \\
\cline { 2 - 4 } & $\mathrm{B}$ & Std. Error & Beta & & \\
\hline Constant & 1.515 & 0.573 & & 2.645 & 0.010 \\
\hline Power (KW) & -0.073 & 0.009 & -0.336 & -8.457 & 0.000 \\
\hline $\begin{array}{l}\text { RPM } \\
\text { (cycle/min) }\end{array}$ & 0.149 & 0.049 & 0.127 & 3.072 & 0.003 \\
\hline $\begin{array}{l}\text { Thrust per } \\
\text { Cutter (KN) }\end{array}$ & 0.266 & 0.048 & 0.241 & 5.529 & 0.000 \\
\hline GSI & 0.374 & 0.058 & 0.350 & 6.400 & 0.000 \\
\hline
\end{tabular}

*a. Dependent Variable: Number of consumed disc cutter

Number of consumed disc cutter $=0.42+$

$+0.0028 P O W E R+0.56 R P M-0.02 R P M^{2}+$

+0.037 Thrust per Cutter ${ }^{0.896}+0.179 G_{S I}^{0.88}$

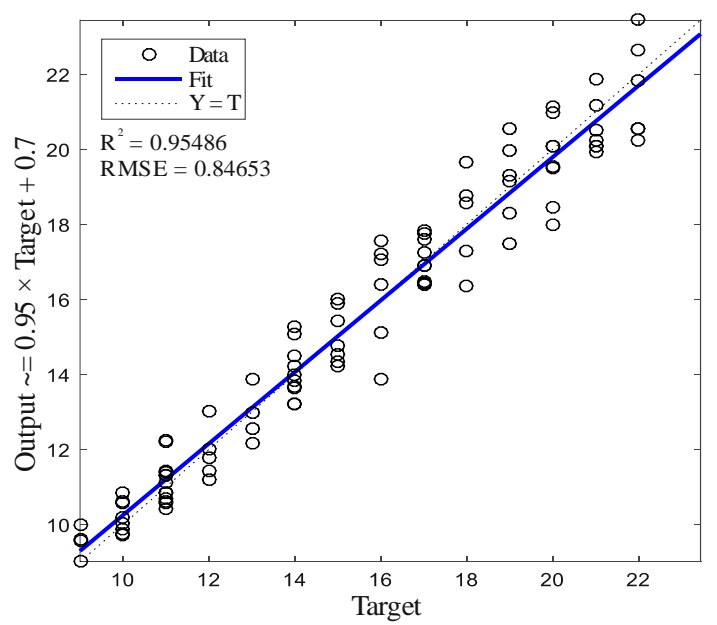

Figure 4. Distribution diagram by nonlinear regression

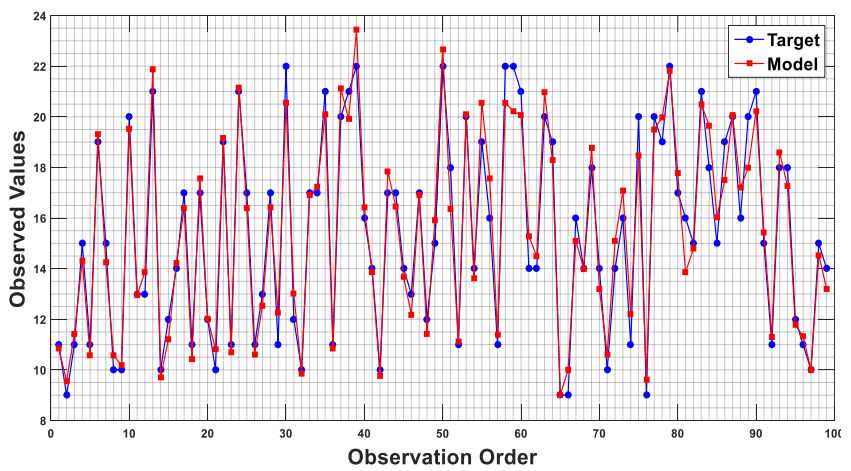

Figure 5. Diagram of matching by nonlinear regression 


\subsection{Predicting by the Gene} Expression Programming Model

The coefficient of determination $\left(R^{2}\right)$ and the root mean square error (RMSE) and distribution diagram of the Gene Expression Programming Model (GEP) for predicting the number of consumed disc cutters in the Sabzkooh water conveyance tunnel are shown in Figure 6. The matching diagram of the measured values of the number of consumed disc cutters or target and the predicted values of the number of consumed disc cutters by the GEP predictive model is shown in Figure 7.

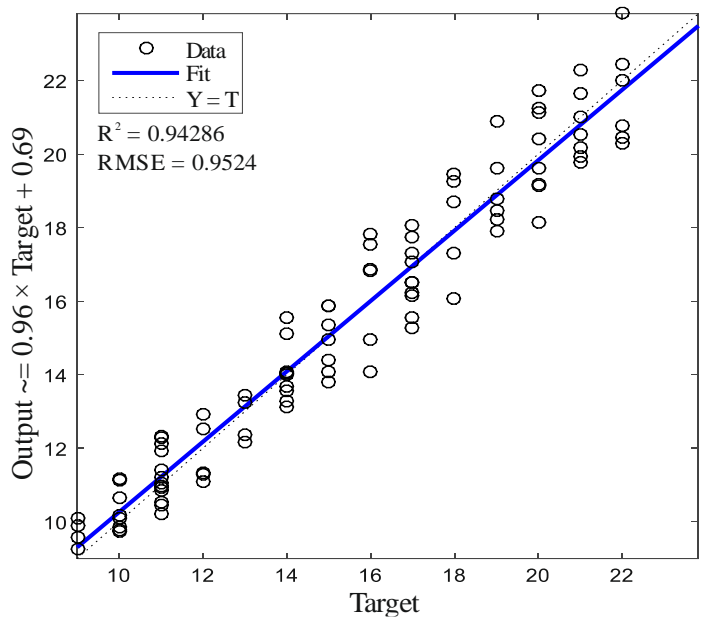

Figure 6. Distribution diagram by GEP

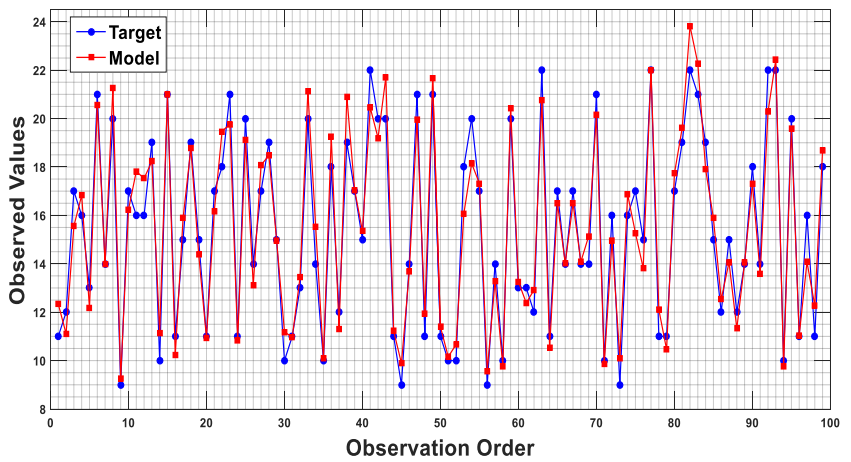

Figure 7. Diagram of matching by GEP

Tree expression of predictive relation of cutters in this tunnel, created by the GEP model, is shown in Figure 8 between input variables and the number of consumed disc cutters. The mathematical expression of this equation is described in Equation (3):

$$
\begin{aligned}
& E T 1=\sqrt{\sqrt{\sqrt[3]{e^{\sqrt{\text { Thrust per Cutter }+ \text { POWER }}}}-\text { POWER }}} ; \\
& E T 2=\sqrt{\sqrt{G S I} \cdot \text { RPM }} ; \\
& E T 3=\sqrt{\frac{1}{\sqrt{\sqrt{R P M+2.17} \cdot e^{R P M} \cdot 2.17}}} .
\end{aligned}
$$

\subsection{Predicting the number of consumed disc cutters in the Sabzkooh water conveyance tunnel by the Support Vector Machine Model}

The coefficient of determination $\left(R^{2}\right)$ and the root mean square error (RMSE) and distribution diagram of the Support Vector Machine Model (SVM) for predicting the number of consumed disc cutters in the Sabzkooh water conveyance tunnel are shown in Figure 9.

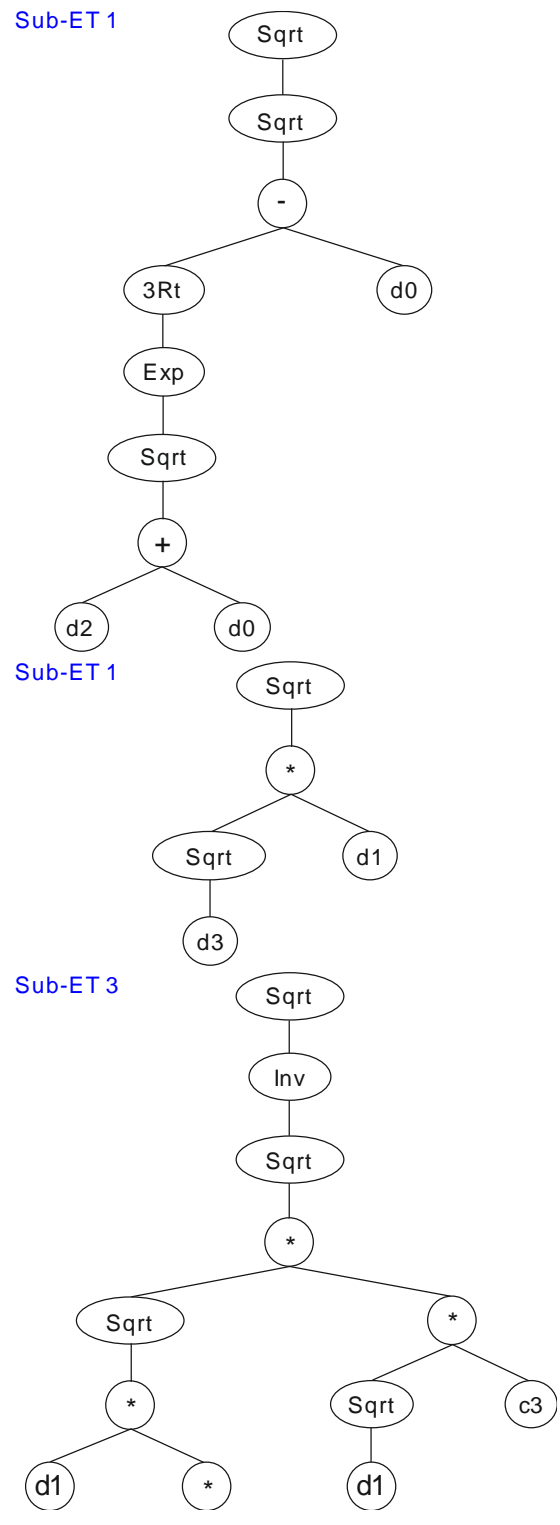

Figure 8. Expression tree of predictive relation between the number of consumed disc cutters by GEP model in Sabzkooh water conveyance tunnel

The matching diagram of the measured values of the number of consumed disc cutters or target and the predicted values of the number of consumed disc cutters by the SVM predictive model is shown in Figure 10.

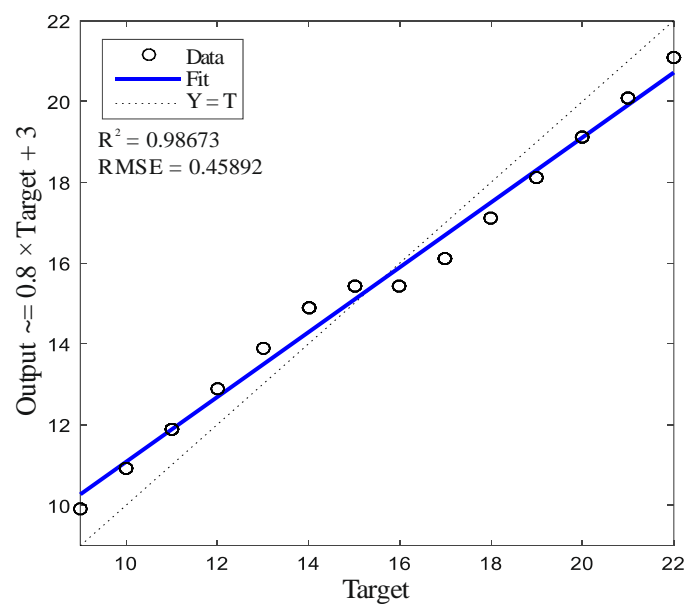

Figure 9. Distribution diagram by SVM 


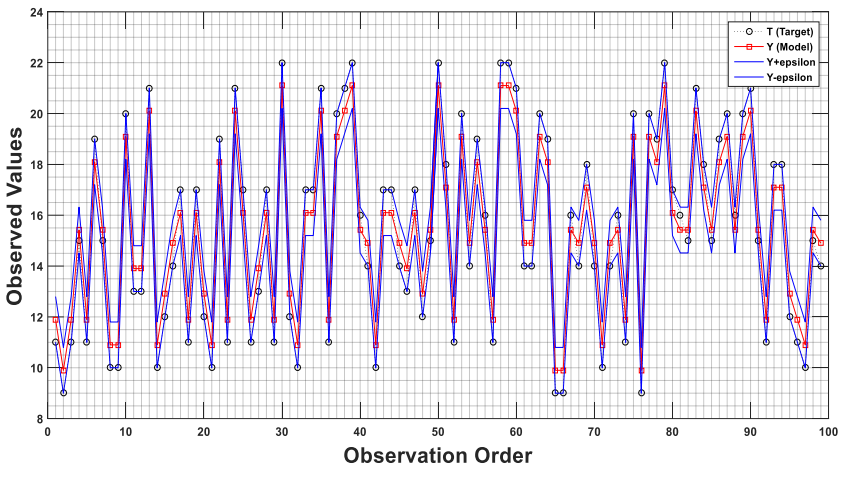

Figure 10. Diagram of matching by SVM

\section{Conclusions}

By the rapid development of tunnel and technology of underground spaces, increasingly tunnel boring machine (TBM) play an important role in hard rock tunnel excavating. The mechanized excavating technique in the construction of the tunnel has attracted much attention due to many advantages over other common methods. Tunnel boring machine is often used to excavate long tunnels under various geological conditions. With the rapid growth of tunnel boring machines in rock tunnel projects around the world, especially over the past two decades, it is required to be predicted the number of consumed disc cutters. Predicting the number of consumed disc cutters is an important factor in improving the performance of tunnel boring machines. TBM rock cutting is accomplished by the cutterhead.

The cutting tools on the cutterhead are the parts which interact directly with rocks. Number of consumed disc cutter is a crucial problem that influences the working efficiency of tunnel boring machines (TBMs). In this study, linear and nonlinear multivariate regression analysis, GEP and SVM were used to predict the number of consumed disc cutters in the Sabzkooh water conveyance tunnel and to predict the number of consumed disc cutters, four parameters of Power (KW), Revolutions per minute (RPM)(cycle/min), Thrust per Cutter (KN), Geological Strength Index (GSI) as independent variables and the number of consumed disc cutters are considered as a dependent variable. In this study, in order to evaluate the accuracy and efficiency of predictive models of TBM disc cutters, the index of coefficient of determination $\left(R^{2}\right)$ and root mean square error (RMSE) is used.

Results showed that number of consumed disc cutter for linear regression method is $R^{2}=0.95$ and $\mathrm{RMSE}=0.83$, nonlinear regression method is $R^{2}=0.95$ and $\mathrm{RMSE}=0.84$, Gene Expression Programming (GEP)method is $R^{2}=0.94$ and RMSE $=0.95$, Support Vector Machine (SVM) method is $R^{2}=0.98$ and $\mathrm{RMSE}=0.45$. According to the results all four methods have high accuracy, with the difference that the support vector machine has a special superiority over other methods.

\section{Acknowledgements}

The authors would like to thank the anonymous reviewers and editor for their valuable comments.

\section{References}

[1] Akiyama, T. (1970). A theory of the rock-breaking function of the disc cutter. Komatsu Technology, 16(3), 56-61.
[2] Evans, I. (1974). Relative efficiency of picks and discs for cutting rock. Proceedings of $3^{\text {rd }}$ Congress on Advances in Rock Mechanics, 1399-1406.

[3] Snowdon, R., Ryley, M., \& Temporal, J. (1982). A study of disc cutting in selected British rocks. International Journal of Rock Mechanics and Mining Sciences \& Geomechanics Abstracts, 19(3), 107-121. https://doi.org/10.1016/0148-9062(82)91151-2

[4] Sanio, H. (1985). Prediction of the performance of disc cutters in anisotropic rock. International Journal of Rock Mechanics and Mining Sciences \& Geomechanics Abstracts, 22(3), 153-161. https://doi.org/10.1016/0148-9062(85)93229-2

[5] Rostami, J. (1997). Development of a force estimation model for rock fragmentation with disc cutters through theoretical modeling and physical measurement of the crushed zone pressure. Doctorate Dissertation. Golden, United States: Colorado School of Mines.

[6] Frenzel, C., Sling, H.K., \& Thuro, K. (2008). Factors influencing disc cutter wear. Geomechanics and Tunnelling, 1(1), 55-60. https://doi.org/10.1002/geot.200800006

[7] Roby, J., Sandell, T., Kocab, J., \& Lindbergh, L. (2008). The current state of disc cutter design and development directions. Proceedings of 2008 North American Tunneling Conference.

[8] Lin, Q., Cao, P., Li, K., Cao, R., Zhou, K., \& Deng, H. (2018). Experimental study on acoustic emission characteristics of jointed rock mass by double disc cutter. Journal of Central South University, 25(2), 357-367. https://doi.org/10.1007/s11771-018-3742-7

[9] Ren, D.-J., Shen, S.-L., Arulrajah, A., \& Cheng, W.-C. (2018). Prediction model of tbm disc cutter wear during tunnelling in heterogeneous ground. Rock Mechanics and Rock Engineering, 51(11), 3599-3611. https://doi.org/10.1007/s00603-018-1549-3

[10] Peng, X., Liu, Q., Pan, Y., Lei, G., Wei, L., \& Luo, C. (2017). Study on the influence of different control modes on TBM disc cutter performance by rotary cutting tests. Rock Mechanics and Rock Engineering, 51(3), 961-967. https://doi.org/10.1007/s00603-017-1368-y

[11] Pan, Y., Liu, Q., Liu, J., Peng, X., \& Kong, X. (2018). Full-scale linear cutting tests in chongqing sandstone to study the influence of confining stress on rock cutting forces by TBM disc cutter. Rock Mechanics and Rock Engineering, 51(6), 1697-1713. https://doi.org/10.1007/s00603018-1412-6

[12] Tan, Q., Yi, L., \& Xia, Y.M. (2018). Performance prediction of TBM disc cutting on marble rock under different load cases. KSCE Journal of Civil Engineering, 22(4), 1466-1472. https://doi.org/10.1007/s12205017-1048-1

[13] Zhang, X., Xia, Y., Tan, Q., \& Wu, D. (2018). Comparison study on the rock cutting characteristics of disc cutter under free-face-assisted and conventional cutting methods. KSCE Journal of Civil Engineering, 22(10), 4155-4162. https://doi.org/10.1007/s12205-018-0577-6

[14] Xia, Y., Lin, L., Wu, D., Jia, L., Chen, Z., \& Bian, Z. (2018). Geological adaptability matching design of disc cutter using multicriteria decision making approaches. Journal of Central South University, 25(4), 843-854. https://doi.org/10.1007/s11771-018-3788-6

[15] Talary, G.A., Rahimi, E., \& Abbasi, M. (2016). Seismotectonics and earthquake risk analysis in the area of Sabzkooh-Choqakhor water conveyance tunnel. Thirty-Fourth Gathering and Second International Congress of Geosciences.

[16] Yoon, G.L., Kim, B.T., \& Jeon, S.S. (2004). Empirical correlations of compression index for marine clay from regression analysis. Canadian Geotechnical Journal, 41(6), 1213-1221. https://doi.org/10.1139/t04-057

[17] Wang, S., Zheng, L., \& Dai, J. (2014). Empirical likelihood diagnosis of modal linear regression models. Journal of Applied Mathematics and Physics, 2(10), 948-952. https://doi.org/10.4236/jamp.2014.210107

[18] Quirós, E., Felicísimo, A.M., \& Cuartero, A. (2009). Testing multivariate adaptive regression splines (MARS) as a method of land cover classification of TERRA-ASTER satellite images. Sensors (Basel, Switzerland), 9(11), 9011-9028. https://doi.org/10.3390/s91109011

[19] Bates, D.M., \& Watts, D.G. (1988). Nonlinear regression analysis and its applications. New York, United States: John Wiley \& Sons. https://doi.org/10.1002/9780470316757

[20] Huang, C., \& Townshend, J.R.G. (2003). A stepwise regression tree for nonlinear approximation: applications to estimating subpixel land cover. International Journal of Remote Sensing, 24(1), 75-90. https://doi.org/10.1080/01431160305001

[21] Brimacombe, M. (2016). Local curvature and centering effects in nonlinear regression models. Open Journal of Statistics, 6(1), 76-84. https://doi.org/10.4236/ojs.2016.61010

[22] Fiore, A., Quaranta, G., Marano, G., \& Monti, G. (2016). Evolutionary polynomial regression-based statistical determination of the shear capacity equation for reinforced concrete beams without stirrups. Journal of Computing in Civil Engineering, 30(1), 04014111. https://doi.org/10.1061/(ASCE)CP.1943-5487.0000450 
[23] Giustolisi, O., \& Savic, D.A. (2006). A symbolic data-driven technique based on evolutionary polynomial regression. Journal of Hydroinformatics, 8(3), 207-222. https://doi.org/10.2166/hydro.2006.020b

[24] Ferreira, C. (2001). Gene expression programming: A new adaptive algorithm for solving problems. Complex Systems, 13(2), 87-129.

[25] Tsai, H.C. (2011). Using weighted genetic programming to program squat wall strengths and tune associated formulas. Engineering Applications of Artificial Intelligence, 24(3), 526-533. https://doi.org/10.1016/j.engappai.2010.08.010

[26] Azamathulla, H.M. (2013). Gene-expression programming to predict friction factor for Southern Italian Rivers. Neural Computing and Applications, 23(5), 1421-1426. https://doi.org/10.1007/s00521-012-1091-2

[27] Roushangar, K., Mouaze, D., \& Shiri, J. (2014). Evaluation of genetic programming-based models for simulating friction factor in alluvial channels. Journal of Hydrology, (517), 1154-1161. https://doi.org/10.1016/j.jhydrol.2014.06.047

[28] Gandomi, A.H., \& Roke, D.A. (2015). Assessment of artificial neural network and genetic programming as predictive tools. Advances in Engineering Software, (88), 63-72, https://doi.org/10.1016/j.advengsoft.2015.05.007

[29] Azamathulla, H.M., Ghani, A.A., Chang, C.K., Hasan, Z.A., \& Zakaria, N.A. (2010). Machine learning approach to predict sediment load-a case study. CLEAN Soil Air Water, 38(10), 969-976, https://doi.org/10.1002/clen.201000068

[30] Shirzad, A., Tabesh, M., \& Farmani, R. (2014). A comparison between performance of support vector regression and artificial neural network in prediction of pipe burst rate in water distribution networks. KSCE
Journal of Civil Engineering, 18(4), 941-948. https://doi.org/10.1007/s12205-014-0537-8

[31] Wang, W.C., Xu, D.M., Chau, K.W., \& Chen, S. (2013). Improved annual rainfall-runoff forecasting using PSO-SVM model based on EEMD. Journal of Hydroinformatics, 15(4), 1377-1390. https://doi.org/10.2166/hydro.2013.134

[32] Chiang, J., \& Tsai, Y. (2011). Suspended sediment load estimate using support vector machines in Kaoping River Basin. In Consumer Electronics, Communications and Networks (CECNet), International Conference, 1750-1753. https://doi.org/10.1109/CECNET.2011.5769267

[33] Jajarmizadeh, M., Kakaei Lafdani, E., Harun, S., \& Ahmadi, A. (2014). Application of SVM and SWAT models for monthly streamflow prediction, a case study in South of Iran. KSCE Journal of Civil Engineering, 19(1), 345-357. https://doi.org/10.1007/s12205-014-0060-y

[34] Kakaei Lafdani, E., Moghaddam Nia, A., \& Ahmadi, A. (2013). Daily suspended sediment load prediction using artificial neural networks and support vector machines. Journal of Hydrology, (478), 50-62. https://doi.org/10.1016/i.jhydrol.2012.11.048

[35] Roushangar, K., \& Koosheh, A. (2015). Evaluation of GA-SVR method for modeling bed load transport in gravel-bed rivers. Journal of Hydrology, (527), 1142-1152. https://doi.org/10.1016/j.jhydrol.2015.06.006

[36] Afradi, A., Ebrahimabadi, A., \& Hallajian, T. (2020). Prediction of tunnel boring machine penetration rate using ant colony optimization, bee colony optimization and the particle swarm optimization, case study: Sabzkooh water conveyance tunnel. Mining of Mineral Deposits, 14(2), 75-84. https://doi.org/10.33271/mining14.02.075

\section{Прогнозування кількості витрачених дискових фрез тунелепрохідницького} комбайна із використанням інтелектуальних методів

\section{А. Афраді, А. Ебрагімабаді, Т. Халладжян}

Мета. Вибір правильної моделі для прогнозування кількості витрачених дискових фрез у проектах механізованої проходки тунелів.

Методика. У цьому дослідженні кількість витрачених дискових фрез була розрахована з урахуванням характеристик комбайна та грунту, таких як потужність (кВт), кількість обертів за хвилину (об/хв) (цикл/хв), зусилля на фрезу (кН), індекс геологічної міцності (GSI) для умов водопровідного тунелю Сабзкох. Прогнозування було проведено за допомогою множинного лінійного та нелінійного регресійного аналізу, методу програмування експресії генів (GEP) та методу опорних векторів (SVM). B ході аналізу для оцінки точності та ефективності прогнозних моделей використовувалися коефіцієнт детермінації $\left(R^{2}\right)$ та середньоквадратична помилка (RMSE).

Результати. Результати показали, що при прогнозуванні кількості витрачених дискових фрез методом лінійної регресії $R^{2}=0.95$ та RMSE $=0.83$, методом нелінійної регресії $-R^{2}=0.95$ та RMSE $=0.84$, методом програмування експресії генів (GEP) $R^{2}=0.94$ та RMSE $=0.95$, і методом опорних векторів $(\mathrm{SVM})-R^{2}=0.98$ та RMSE $=0.45$. Результати показали, що всі чотири методи ефективні та мають високу точність, але метод опорних векторів має перевагу перед іншими методами.

Наукова новизна. Встановлено характер розподілу та відповідності між виміряними значеннями кількості витрачених дискових фрез та прогнозованою кількістю витрачених дискових фрез за допомогою різних методів математичного моделювання.

Практична значимість. Визначено оптимальний метод прогнозування витрати дискових фрез, що дозволяє підвищити ефективність проходження тунелів.

Ключові слова: прохідницький комбайн, регресійний аналіз, програмування експресії генів, метод опорних векторів, водопровідний тунель

\section{Прогнозирование количества израсходованных дисковых фрез тоннелепроходческого комбайна с использованием интеллектуальных методов}

\section{А. Афради, А. Эбрагимабади, Т. Халладжян}

Цель. Выбор правильной модели для прогнозирования количества израсходованных дисковых фрез в проектах механизированной проходки туннелей.

Методика. В данном исследовании количество израсходованных дисковых фрез было рассчитано с учетом характеристик комбайна и грунта, таких как мощность (кВт), число оборотов в минуту (об/мин) (цикл/мин), усилие на фрезу (кН), индекс геологической прочности (GSI) для условий водопроводного тоннеля Сабзкох. Прогнозирование было проведено с помощью множественного линейного и нелинейного регрессионного анализа, метода программирования экспрессии генов (GEP) и метода опорных векторов (SVM). В ходе анализа для оценки точности и эффективности прогнозных моделей использовались коэффициент детерминации $\left(R^{2}\right)$ и среднеквадратичная ошибка (RMSE).

Результаты. Результаты показали, что при прогнозировании количества израсходованных дисковых фрез методом линейной регрессии $R^{2}=0.95$ и RMSE $=0.83$, методом нелинейной регрессии $-R^{2}=0.95$ и RMSE $=0.84$, методом программирования экспрессии генов $(\mathrm{GEP})-R^{2}=0.94$ и RMSE $=0.95$, и методом опорных векторов $(\mathrm{SVM})-R^{2}=0.98$ и RMSE $=0.45$. Результаты показали, что все четыре метода эффективны и обладают высокой точностью, но метод опорных векторов имеет преимущество перед другими методами.

Научная новизна. Установлен характер распределения и соответствия между измеренными значениями количества израсходованных дисковых фрез и прогнозируемым количеством израсходованных дисковых фрез при помощи различных методов математического моделирования.

Практическая значимость. Определен оптимальный метод прогнозирования расхода дисковых фрез, что позволяет повысить эффективность проходки туннелей.

Ключевые слова: проходческий комбайн, регрессионный анализ, программирование экспрессии генов, метод опорных векторов, водопроводный тоннель 